\section{UNUSUAL WINTER BIRD RECORDS FROM SOMME, SASKATCHEWAN}

DONALD HOOPER, P.O. Box 40, Somme, Saskatchewan. SOE 1NO

On 30 March 1980 I was called to visit Stan Back's bird feeder at Carragana to identify a strange bird that was feeding on sunflower seeds with a large flock of Evening Grosbeaks. It was a large sparrow with a stout, pink bill, a mottled black and white throat, and streaked sides. I hadn't seen a plumage quite like it before, but after a check with Robbins, Bruun and Zim's Birds of North America I realized that a pinkbilled sparrow with streaked sides could only be a Harris' Sparrow. It was in its first winter plumage, changing from a white throat to a black throat. By the time it left on 12 April its throat was even blacker. Stan reported that this individual had been present since midFebruary, our first winter record for the Somme area.

Our earliest spring date for the Harris Sparrow at Somme is 30 April (1959) and the latest spring departure 4 June (1954). When the males arrive, their throats are always black.

In the winter of 1971-72 a Western Meadowlark stayed with a herd of cattle north of Somme and was seen until the end of March. It slept in a hole in a bale stack.

While logging south of Dillabough in January 1955, I saw a White-throated Sparrow feeding with the chickadees at The Pas Lumber Company's garbage dump. It was very tame and was observed at close range from 22 to 31 January, when we moved the camp.

A Song Sparrow stayed around our farmyard $2 \mathrm{mi}$. east and $3 \mathrm{mi}$. north of Somme, from 21 December 1953 through 1 January 1954.
A rare visitor, a Clark's Nutcracker, came to David Black's feeder, $4.5 \mathrm{mi}$. north of Somme on 21 October 1979.

We also have an occasional Starling, Horned Lark, and Dark-eyed Junco that loses all urge to migrate and braves the winter cold, but such events are less noteworthy.

LINDSAY WOTHERSPOON, P.O. BOX 13-36, Swan River, Manitoba. POL $1 Z 0$

In 1932 or 1933 four or five of us young blokes were on the way from Hyas, Saskatchewan to Peepaw Lake for some ice fishing, travelling by sleigh and team. On the way through the Porcupine Forest Reserve south of Peepaw Lake, an owl was seen in the lower branches of a tree. A fellow with a .22 shot at it and missed, and the owl moved about 100 yards farther along the trail. Again he shot and missed. This was repeated three or four times. Finally he spied it almost out of sight to the side of the trail. He shot from the hip without raising the sights. Down went the owl. After taking measurements and comparing it with Taverner's Birds of Western Canada, we identified it as a Cinereous or Great Gray Owl.

Since we moved to the Woody River valley along the SaskatchewanManitoba boundary, I identified the remains of another owl shot by a Kamsack hunter near here about 1960. It was at dusk of an unlucky day's hunt and he shot it out of a tree with his 30.06 .

I don't know why people shoot owls. 